\title{
THE SCOPE OF CONTROL OF THE SUPREME AUDIT OFFICE IN THE SLOVAK REPUBLIC AND IN THE OTHER VISEGRAD FOUR COUNTRIES
}

\author{
LENKA HUDÁKOVÁ STAŠOVÁ \\ Department of Finance, Faculty of Economics, Technical University of Košice, Slovakia \\ Email: lenka.hudakova.stasova@tuke.sk
}

In this contribution, we evaluate the performance of the Supreme Audit Office's (SAO) audit activity in the Visegrad Four (V4) countries. We focus on the analysis of the control activities of the SAO of the Slovak Republic and we compare the results with other countries. We focused on the SAO's function control, according to the number of controls undertaken over the period 20142016, and evaluated an auditors's burden (the number of controls performed by one inspector). We state the positives, but also the risks of expanding the area of control over the self-government bodies, and we put forward proposals to reduce these risks. Slovakia, the Czech Republic, Hungary and Poland have the same or similar historical trajectories, cultural and intellectual values and they share common roots of religious traditions. Therefore we assume that they may display certain key similarities in institutional development, including in the area of public finance control. We review how these countries have worked in the area today, with a focus on the period between 2014 and 2016.

Keywords: control systems in public administration, scope of control, Supreme Audit Office, control in the state administration, control in self-government

JEL-codes: H72, H73, H83 


\section{INTRODUCTION}

Audit is a feedback system that gives a clear answer to the question of whether the actual state corresponds to the desired situation. Financial audit is one of the tools for verifying the spending of public funds in accordance with the law and other conditions. Unlike its meaning in the private sphere, the institute of audit in the public administration acquires a special significance that is manifested in several ways. In particular, the importance of audit in public administration manifests itself in the legislative regulation of its implementation (in the legal process of law enforcement) and also in its institutionalization (in the formal creation of control bodies at individual levels of public administration and its orders of importance). It is precisely because of its complexity that public administration audit is increasingly gaining in prominence.

The main aim of the paper is to assess the work of the Supreme Audit Offices (SAOs) in the Visegrad Four (V4) countries in terms of the scope of their control. For the analysis, we chose the four countries of the Central European region, which are neighboring countries and formerly classified as transition economies. Slovakia, the Czech Republic, Hungary and Poland have always been part of the same civilization based on the same cultural and intellectual values and have common roots of religious traditions. Therefore, they have a common ground also in the area of public finance control. We review how these countries have recently performed in the area today.

The aim is to also specify the risks in the area of control activity of the SAO and to submit proposals for their mitigation.

In light of the above, the paper is divided into three main parts. The first part provides a literature review topic, focusing on identifying the importance of control in public administration. In the second part of the paper, we analyse the scope of the control of the SAO in all four V4 countries, and evaluate the number of audited entities in both absolute and percentage terms, as well as the number of audited entities performed by one auditor (controller). We compare data for all countries. The analysis covers the years between 2014 and 2016. The third part of the paper summarises the results of the analysis, specifies the risks and offers suggestions for their mitigation.

\section{THE IMPORTANCE OF AUDIT IN PUBLIC ADMINISTRATION}

Audit is an indispensable element of public administration activity. Public administration, just like every social organization, contains in itself sources of mistakes and bureaucratic structures. By auditing public administration both externally 
and internally, we also seek to prevent the degeneration of power, manifested in power abuse. Therefore, one of the basic prerequisites for good and successful audit is the independence of the auditor from the auditee (Hendrych 2009; Redmayne et al. 2010). Public administration audit is a specific way of managing public affairs. There must be a comprehensive system of reverse audit in the public administration, which constitutes a public administration control system. The purpose of the audit is to critically assess the state of affairs and to remedy the shortcomings that affect the performance and the mission of the public administration organization (Tej 2002). Audit, as a term of administrative law, means an activity which assesses and evaluates whether and how the activities of legal and natural persons subject to audit comply with certain requirements laid down in legal standards or acts (Nikodým 1969). The term audit is also considered to be a compound word of French etymology originating in the Latin language, which expresses a phenomenon or an activity that we can call inspection, comparison, examination, supervision, keeping an eye on, or (an international term) review. Audit, 'contrôle' in French, actually means a role against a role or, figuratively, a task against a task or a document against a document. In our opinion, the most succinct meaning is conveyed by understanding the audit as (one) state of affairs versus (the second, the other) state of affairs (Králik - Kútik 2013; Klierová Kútik 2017).

In connection with the above, it is still necessary to refer to the definition of audit by the International Organization of Supreme Audit Institutions (INTOSAI), which at its $9^{\text {th }}$ Congress (1977) in Lima adopted a declaration on basic principles of an independent audit. Under the Lima Declaration, the audit is not an end in itself, but it is an integral part of public funds management and of the regulatory system thereof. In addition, in the context of the Lima Declaration, the task of the audit is to signal deviations from standards, breach of legislation or failure to meet the requirements of economy and effectiveness so that it is possible to apply corrective measures in individual cases, compensate for the damage caused or take the necessary measures to prevent the recurrence of identified deficiencies in the future.

The Lima Declaration is important for the definition and application of audit. It defines that the audit is a natural part of public finance management because public finance management is the management of public resources. The audit is not performed in isolation - it is an integral part of the management system aimed at timely detection of deviations from accepted standards and of breaches of the principles of efficiency and cost-effectiveness of financial management so that remedial action can be taken in individual cases to prevent such breaches, or at least make it difficult for them to re-occur (Oláh 2005; 2009; Nemec et al. 2010; Matějová et al. 2017). Audit is an integral part of management and decision- 
making processes. It constitutes an act and a process that through feedback provide information on the achievement of goals. As a management subsystem, audit can also be defined based on its specific functions, which we understand to be regulation, negation and motivational, educational and institutional tools (Benčo et al. 2001; Iacovino et al. 2017).

Controls carried out in public administration should ensure that all necessary activities are carried out to the appropriate extent and time. They should focus on the identification of facts as a prerequisite for predicting the controlled phenomenon and the correct identification of future goals. It should allow identifying and subsequently removing the negative deviations found during the inspection, generally applying the results of the controlled activity (Maličká 2017; Rakšnys - Valickas 2016; Halásková 2017).

The purpose of the control activity in public administration is to ensure that the public authorities have paid due attention to the measures taken, in order not to breach laws and legal standards, to avoid uneconomical and inefficient performance of tasks, as well as the uneconomic management of public resources and state assets. The aim of any control should undoubtedly be the very interest of learning from existing shortcomings and preventing them from happening in the future. It is necessary to ensure that day-to-day control is a part of governance in public administration, leading to credibility and transparency at all levels (Jankovics 2016; Meričková et al. 2015; Nemec 2015; Reddy et al. 2015).

Control in the public sector should continually provide incentives to improve all processes and serve as a medium of creating a better relationship between the citizen, the public sector and the public administration (Bovaird - Löffler 2003). Public administration has an important mission within public power and, in a certain sense, in the area of private control as well. The most important part of the public administration control activity is that the activity of the public administration has been examined not only by the legislative power and the judiciary, but also by the general public (Barett 2012; Beetham - Weir 2000; Brusca 2015). Public administration itself comprises audit as an integral part of its own activity and is subject to audit by other entities. In the general sense of the word, public administration audit ensures that all necessary activities are carried out in the appropriate scope, direction and time (Škultéty 2008; Medved' et al. 2011; Špalková et al. 2015).

Public sector auditing has not been as widely examined as it should. In many cases, public sector auditors have a responsibility for value for money auditing as well as for financial statement auditing (Buchanan - Simpkins 2001; Hay Cordery 2018). Supreme audit institutions are national agencies responsible for auditing government revenue and spending. Their legal mandates, reporting relationships, and effectiveness vary, reflecting different governance systems and 
government policies. But their primary purpose is to oversee the management of public funds and the quality and credibility of governments' reported financial data (Cordery - Hay 2018; Nagy 2012; Stapenhurst - Titsworth 2001).

By respecting various theoretical approaches to defining the concept of audit, the audit or control activity can be characterized as a set of activities investigating the actual state of affairs by checking the phenomenon, activity or matter subject to audit, which must then be compared with the desired state of affairs (for example, a state required by the applicable legislation), with subsequent identification of the causes of non-compliance between the actual and the desired state of affairs, with measures proposed to remedy the non-compliance and the causal effects and to prevent recurrence of these deficiencies in the future.

In view of the abovementioned approaches to defining the notion of audit in general, it can be stated that the individual activities carried out in course of the audit represent a dynamic process of cross-sectional and universal nature, always having the same goal, the review of the factual state of affairs.

\section{METHODOLOGY AND OBJECTIVES}

The current public administration control system is based on relatively independent control bodies that undertake their control activities and have legal support in each of the V4 countries, in particular the control exercised by the Supreme Audit Institutions. The Supreme Audit Office (SAO) is a state body that is independent in its control activity and performs so-called external controls.

The main aim of the paper is to assess the work of the Supreme Audit Institutions in the V4 countries in terms of the scope of their control. The aim is to also specify the risks in the area of control activity of the SAO and to submit proposals for their mitigation.

In order to meet the stated goal of the contribution, we evaluate the operation and activity of the SAO in the Slovak Republic and we compare the results with other V4 countries. We are focusing on analysing the number of audited entities in all countries over a recent three-year period. We compare the ratio of the audited entities in individual years to the total number of entities within the SAO's controlling scope. We also evaluate the ratio between the number of audited entities and the number of controllers in each country, i.e. we evaluate the indicator of the number of audited entities by one SAO controller. We present the results of the analyses in tables that have the same structure for all countries except the Czech Republic. This is because the Czech Republic has a different scope of control compared to the other three analysed countries. The scope of control of the SAOs of Slovakia, Hungary and Poland is the entire public administration, 
while the scope of control of the SAO of the Czech Republic does not include local administrations (self-governments). To ensure comparability, we also perform the analysis by omitting the self-governing bodies. We are therefore evaluating at two levels - at the level of the entire public administration and separately at the level of the state administration.

The partial analyses for individual countries are then evaluated by comparison, the results are described, and the data are presented in tables and charts. On the basis of the results, we evaluate the positives as well as possible risks.

The data for the analysis has been obtained partly from annual reports of the public administration bodies and mainly through controlled interviews with the staff of the Supreme Audit Institutions in each analysed country. The data include the number of all public administration bodies under the SAO's scope of control in each country, data on the number of actually audited entities in each of the three evaluated years (broken down into the entities inspected in the state administration and separately those inspected in the local self-governing administration), and the data on the number of SAO auditors (controllers) authorised to perform the audit.

\section{AUDITS PERFORMED BY SAOS}

An important prerequisite for the good functioning of a modern democratic state is the independent audit of how the state is managed. Any state that wants to operate efficiently needs a supervisory body, independent of the executive branch, to protect public finances. In the democratic world, such institutions are a standard. In all countries under our assessment, this role is held by similar control institutions, the supreme audit offices.

In the Slovak Republic, the formation of the Supreme Audit Office (Najvyšši kontrolný úrad) is regulated in the second section of the third chapter of the Slovak Republic's Constitution. Pursuant to Article 63 of the Constitution of the Slovak Republic, the definition of the status, scope, organizational division, as well as the rules of inspection activity, shall be further stipulated by the law. This law is the Act No. 39/1993 Statutes on the Supreme Audit Office of the Slovak Republic, which defines the SAO as a state authority independent in its control activity and bound exclusively by law. In carrying out its control activities, the SAO of the Slovak Republic proceeds in accordance with this Act, with the International Standards of Supreme Audit Institutions (ISSAI) issued by the International Organization of Supreme Audit Institutions (INTOSAI), as well as in accordance with the Implementation Guidelines of the INTOSAI European Standards, which develops the INTOSAI standards in more detail and provides guidance on their practical application. 
The scope of SAO control in the Slovak Republic applies to the government, ministries and other central authorities of the state administration and their subordinate bodies, state authorities as well as legal entities of which the founder is the central state administration or other state authorities, special purpose state funds, public bodies established by law, legal entities with shareholders that are public institutions, legal entities with one of the shareholders being the state, natural persons and legal entities. In addition, the SAO is authorized to exercise its controlling authority over the municipalities and higher territorial units, legal entities established by municipalities, legal entities established by higher territorial units, legal entities with shareholders that are municipalities and legal entities with shareholders that are higher territorial units.

In the Czech Republic, the existence of the Supreme Audit Office (Nejvyšší kontrolní úrad) is enshrined in the Constitution of the Czech Republic and its activity and powers are governed by the Act No. 166/1993 Statutes on the Supreme Audit Office. The SAO fulfills its role independently and is independent of the legislative, the executive and the judicial branch. Adequate financial independence is an integral part of this arrangement. The only determining authority in this respect is the Chamber of Deputies of the Parliament of the Czech Republic, which also controls how SAO is managed. The SAO examines the state's management of state property and foreign assets, but as mentioned it does not have control over the funds of municipalities, towns and regions or companies in which one of the shareholders is the state or local administration.

The Supreme Audit Office in Hungary (Állami Számvevőszék) is the highest financial and economic controlling organization. The adoption of the SAO Act was a major change, because it strengthened the SAO's independence, which also meant significant progress in terms of transparency. Hungary thus complies with international requirements of SAO independence. The objective of the SAO as the highest body of public audit is to ensure the safe, balanced and effective functioning of public finances and to support their development, to increase the transparency of public finance processes and the responsibility for managing public finances. The strategic role is to promote transparency of public finances, the effective and efficient use of public funds and assets, using the methodology and objectives of the international professional organizations INTOSAI and EUROSAI. The SAO's supervisory role in Hungary applies to the state administration as well as the local self-governing authorities as is the case in the Slovak Republic and Poland.

The Supreme Audit Office in Poland (Najwyższa Izba Kontroli) is the highest independent authority of state audit, whose role is to protect public expenditures. Its reports are projected to be continuously sought-after as necessary sources of information for public authorities and the general public alike. The Supreme 
Audit Office was established as one of the first institutions in the restored, independent Poland. It reports to Sejm (lower chamber of the Polish Parliament). The Supreme Audit Office submits its analysis of the state budget execution and the monetary policy guidelines to the Sejm, together with its opinion on the government's vote on the budget approval, statements on the results of audits and annual reports on SAO activities.

The most important audit performed by the SAO is the audit of the state budget. This obligation was imposed on the SAO by the Polish Constitution and the SAO Act. Each inspection activity is carried out in accordance with the SAO audit standards. This enables the SAO to perform its audit activities at a recognized international level. The application of standards has provided a homogeneous platform for planning and conducting audits as well as evaluating their results. In addition to state administration, the SAO's controlling authority in Poland also extends over the authorities of local self-government.

\section{ANALYSIS AND COMPARISON}

Tables 1 to 4 show the number of public entities in the controlling jurisdiction of the SAO in each of the analyzed countries, the number of audited entities in individual years (in absolute and percentage terms) and the calculations of the number of audits performed by a single auditor. The data for each of the monitored years refers to the data from December.

Since it is the SAO's competence to audit the authorities of local self-government in three of the four countries under assessment, for better comparability, we have also made calculations with the omission of authorities of local selfgovernment (AoLSG). This means that we evaluate the data accounting for the entire public administration and separately for the state administration, with the exclusion of authorities of local self-government.

The SAO of the Slovak Republic is authorized to inspect all entities of public administration that meet the conditions set out by the provisions of the SAO SR Act. In carrying out its activity, the Office uses the Database of Public Administration Bodies administered by the Statistical Office of the Slovak Republic. Public administration bodies are legal entities registered in the statistical register of organizations and included in public administration in accordance with the European method ESA 2010 established by the Regulation of the European Parliament and of the Council (EU) no. 549/2013 of May 21, 2013 on the European system of national and regional accounts in the European Union.

In the monitored period in 2014, the Slovak SAO audited $7.02 \%$ of all entities over which it is competent to exercise its control. In 2016, only $4.6 \%$ of entities 
Table 1. Scope of control of the SAO, number of audited entities and number of auditors in the Slovak Republic

\begin{tabular}{|c|c|c|c|}
\hline & 2014 & 2015 & 2016 \\
\hline $\begin{array}{l}\text { Number of entities within the SAO's } \\
\text { scope of control }\end{array}$ & 7634 & 7285 & 7693 \\
\hline Number of audited entities & \begin{tabular}{l}
\multicolumn{1}{c}{536} \\
Out of which: \\
246 AoLSG \\
290 state admin. \\
\end{tabular} & \begin{tabular}{|l}
\multicolumn{1}{|c}{549} \\
Out of which: \\
306 AoLSG \\
243 state admin. \\
\end{tabular} & $\begin{array}{l}\quad 360 \\
\text { Out of which: } \\
\text { 134 AoLSG } \\
226 \text { state admin. }\end{array}$ \\
\hline Number of audited entities in $\%$ & $7.02 \%$ & $7.54 \%$ & $4.70 \%$ \\
\hline $\begin{array}{l}\text { Number of entities of state administra- } \\
\text { tion within the SAO's scope of control } \\
\text { (excluding AoLSGs) }\end{array}$ & 961 & 902 & 937 \\
\hline $\begin{array}{l}\text { Number of audited entities of state } \\
\text { administration / total number of entities } \\
\text { in state administration } \\
\text { (excluding AoLSGs) }\end{array}$ & $30.18 \%$ & $26.94 \%$ & $24.12 \%$ \\
\hline Number of auditors & 228 & 233 & 235 \\
\hline $\begin{array}{l}\text { Total number of audited entities per } \\
\text { auditor }\end{array}$ & 2.351 & 2.356 & 1.532 \\
\hline $\begin{array}{l}\text { Number of audited entities per auditor } \\
\text { (excluding AoLSGs) }\end{array}$ & 1.272 & 1.043 & 0.962 \\
\hline
\end{tabular}

Source: SAO of the Slovak Republic, Statistical Office of the Slovak Republic and the author's calculations

were audited. A single auditor accounts for 2.3 audits performed per year (2014 and 2015). In 2016, a single auditor accounted for 1.5 audits carried out.

We proceed with the evaluation of all the data after omitting the authorities of local self-government, i.e. we leave out from our assessment the municipalities, higher territorial units (VÚC) and the budgetary and contributory organizations established by them. There are 2,927 municipalities and 8 higher territorial units in Slovakia. The budgetary and contributory organizations established by them were 3738 (2014), 3448 (2015) and 3821 (2016). Under such circumstances, $24-30 \%$ of entities were audited in each of the evaluated years. This also reduces the burden on auditors. Under such circumstances, a single auditor may spend an entire year carrying out approximately one audit.

The SAO in the Czech Republic has no competence to audit funds of municipalities, cities and regions, or companies with state or local government as one of their shareholders. The SAO examines the state's management of state property and foreign assets. On the basis of the data obtained, we note that in each year the SAO inspected $27-29 \%$ of all entities in which it is authorized to carry out audits. One auditor accounts for about 0.7 audits performed in each year. 
Table 2. Scope of control of the SAO, number of audited entities and number of auditors in the Czech Republic

\begin{tabular}{l|c|c|c}
\hline & 2014 & 2015 & 2016 \\
\hline $\begin{array}{l}\text { Number of entities within the SAO's scope } \\
\text { of control }\end{array}$ & 755 & 755 & 758 \\
\hline Number of audited entities & 211 & 225 & 208 \\
\hline Number of audited entities in \% & $27.95 \%$ & $29.80 \%$ & $27.44 \%$ \\
\hline Number of auditors & 284 & 285 & 283 \\
\hline $\begin{array}{l}\text { Total number of audited entities per 1 auditor } \\
\text { (controller) }\end{array}$ & 0.743 & 0.790 & 0.735 \\
\hline
\end{tabular}

Source: SAO of the Czech Republic and the author's calculations

Table 3. Scope of control of the SAO, number of audited entities and number of auditors in Hungary

\begin{tabular}{l|c|c|c}
\hline & 2014 & 2015 & 2016 \\
\hline $\begin{array}{l}\text { Number of entities within the SAO's scope } \\
\text { of control }\end{array}$ & 7412 & 7680 & 7654 \\
\hline Number of audited entities & $\begin{array}{c}969 \\
\text { Out of which: } \\
495 \text { AoLSG } \\
474 \text { state admin. }\end{array}$ & $\begin{array}{l}816 \\
\text { Out of which: } \\
281 \text { AoLSG } \\
535 \text { state admin. }\end{array}$ & $\begin{array}{c}\text { 339 AoLSG } \\
\text { Out of which: } \\
500 \text { state admin. }\end{array}$ \\
\hline Number of audited entities in \% & $13.07 \%$ & $10.62 \%$ & $10.96 \%$ \\
\hline $\begin{array}{l}\text { Number of entities of state administration } \\
\text { within the SAO's scope of control } \\
\text { (excluding AoLSGs) }\end{array}$ & 1423 & 1470 & 1439 \\
\hline $\begin{array}{l}\text { Number of audited entities of state admin- } \\
\text { istration / total number of entities in state } \\
\text { administration (excluding AoLSGs) }\end{array}$ & $33.31 \%$ & $36.39 \%$ & $34.75 \%$ \\
\hline $\begin{array}{l}\text { Number of auditors } \\
\text { Total number of audited entities per auditor }\end{array}$ & 1.885 & 1.572 & 1.539 \\
\hline $\begin{array}{l}\text { Number of audited entities per auditor } \\
\text { (excluding AoLSGs) }\end{array}$ & 0.922 & 1.031 & 0.917 \\
\hline
\end{tabular}

Source: SAO of Hungary and the author's calculations

The scope of SAO's control in Hungary is similar to that in Slovakia. Using the evaluated data, we have found that out of all entities under the SAO's auditing jurisdiction, $10-13 \%$ were checked in each year. Thus, one auditor accounts for 1.5-1.8 audits performed per year. If we evaluate the audit activity in the area of state administration only, we find that $33-36 \%$ of all entities were inspected, and that a single auditor does about one audit a year. We also found that in Hungary, out of the total number of audits of local governments all were carried out only in towns, municipalities and budgetary and contributory organizations established by the former. The higher territorial units and their budgetary and contributory organizations were not audited during the entire assessed period. 
THE SCOPE OF CONTROL OF THE SUPREME AUDIT OFFICE IN THE SLOVAK REPUBLIC 255

Table 4. Number of audited entities and number of auditors in Poland

\begin{tabular}{l|c|c|c}
\hline $\begin{array}{l}\text { Number of entities within the SAO's scope } \\
\text { of control }\end{array}$ & 22473 & 22132 & 22398 \\
\hline Number of audited entities & $\begin{array}{l}2483 \\
\text { Out of which: } \\
\text { 924 AoLSG } \\
\text { 1 559 state } \\
\text { admin. }\end{array}$ & $\begin{array}{l}1980 \\
\text { Out of which: } \\
\text { 904 AoLSG } \\
1 \text { 076 state } \\
\text { admin. }\end{array}$ & $\begin{array}{l}2 \text { 494 } \\
\text { Out of which: } \\
\text { 967 AoSG } \\
1527 \text { state } \\
\text { admin. }\end{array}$ \\
\hline Number of audited entities in \% & $11.05 \%$ & $8.94 \%$ & $11.13 \%$ \\
\hline $\begin{array}{l}\text { Number of entities of state administration } \\
\text { within the SAO's scope of control } \\
\text { (excluding AoLSGs) }\end{array}$ & 4272 & 4205 & 4278 \\
\hline $\begin{array}{l}\text { Number of audited entities of state admin- } \\
\text { istration / total number of entities in state } \\
\text { administration (excluding AoLSGs) }\end{array}$ & $36.49 \%$ & $25.58 \%$ & $35.69 \%$ \\
\hline Number of auditors & 1194 & 1156 & 1109 \\
\hline Total number of audited entities per auditor & 2.080 & 1.713 & 2.249 \\
\hline $\begin{array}{l}\text { Number of audited entities per auditor } \\
\text { (excluding AoLSGs) }\end{array}$ & 1.31 & 0.93 & 1.38 \\
\hline
\end{tabular}

Source: SAO of Poland and the author's calculations

The scope of the SAO's control in Poland is the same as is the case in Slovakia and Hungary, which means that it is competent to audit all public administration entities. Data obtained from this country point to the fact that the auditors' load is as large as two complete audits in each year. If we omit the area of selfgovernment, this is reduced to 1.3 audits. In absolute terms, Poland has the highest number of audited entities in individual years between the countries under review, but it also has an incomparably higher number of SAO auditors.

When we compared the Slovak, Czech, Polish and Hungarian data adjusted for comparability (with omission of audits of the authorities of local self-government), we found the greatest number of audited entities in Hungary (33-36\% of all entities in the SAO's jurisdiction), and similar figures are also found in Poland, with the exception of 2015 (25-36\%). Somewhat lower, but still comparable values are found in the other two countries: $27-29 \%$ of audited entities in the Czech Republic, 24-30\% in the Slovak Republic. In absolute terms, most subjects are in the scope of control of the SAO of Poland, which is undoubtedly related to the size of the state. The smallest is the number of entities in the scope of control of the Czech Republic (Figure 1). The auditors in the Czech Republic face the lowest workload, with one SAO auditor auditing 0.7 entities in a calendar year. In Hungary, one auditor audits one entity per year and in Slovakia, one auditor accounts for slightly over one audit performed on the state administration in a 


\section{SCOPE OF CONTROL OF THE SAO AND THE NUMBER OF AUDITED ENTITIES IN THE STATE ADMINISTRATION}

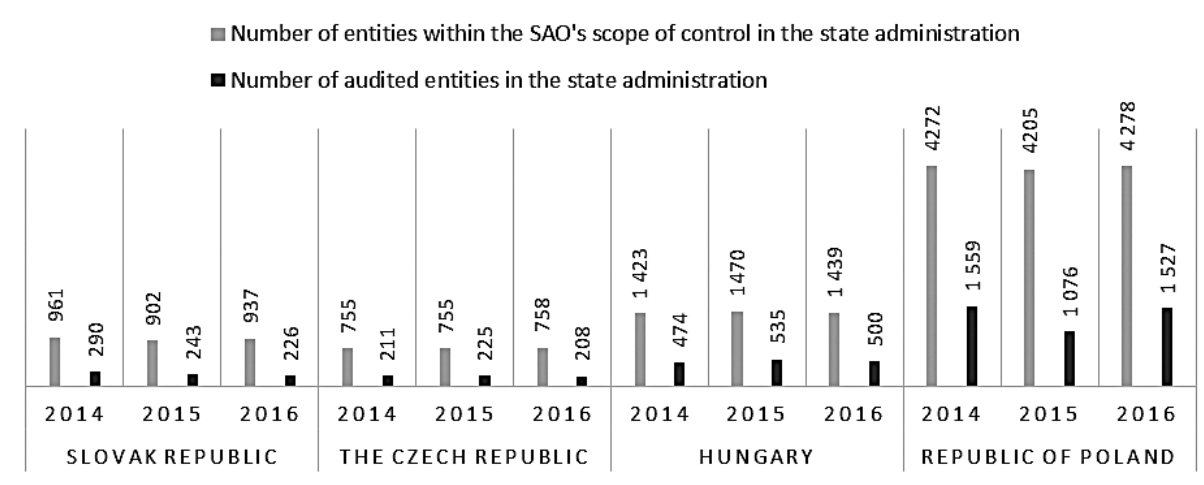

Figure 1. Scope of control of the SAO and the number of audited entities in the state administration

Source: author.

year. The most heavily burdened, according to the number of audits carried out, are the controllers in Poland.

When auditors' workload is compared in terms of the entire scope of the SAO's control authority, the SAO auditors in the Czech Republic face the lowest workload (0.7). In Slovakia, a single auditor audits 1.5-2.3 entities per year, in Hungary the number of audited entities ranges from 1.5 to 1.8 and the highest number of audited entities are found in Poland - 1.7-2.2 per one auditor. In particular, these results are influenced by the fact that the Czech SAO is competent to audit fewer entities in total. This translates into the fact that the Czech SAO shows the highest percentage of audited entities from among all entities under its jurisdiction, i.e. up to almost $30 \%$; for example, only $7 \%$ of entities are audited by the SAO in Slovakia.

Thus, since the SAO in the Czech Republic has no power to audit all public administration bodies (public legal entities) as is the case in Slovakia, the percentage of audited entities is higher. In absolute terms, however, the Slovak SAO annually audits about 2.5 times more entities than its Czech counterpart.

In total, 758 public administration entities fell under the scope of the Czech SAO's control in 2016 (45 budget chapters, 278 organizational units of the state, 209 contributory organizations, 32 state enterprises, 1 national enterprise, 1 state organization, 5 residual national enterprises, 175 national enterprises in liquidation, 7 health insurance companies and 6 state funds). In 2016, 208 entities were audited (27.44 \%). As discussed, the SAO in the Czech Republic lacks control authority over other bodies of public administration. 


\section{SCOPE OF CONTROL OF THE SAO AND THE NUMBER OF AUDITED ENTITIES IN PUBLIC ADMINISTRATION}

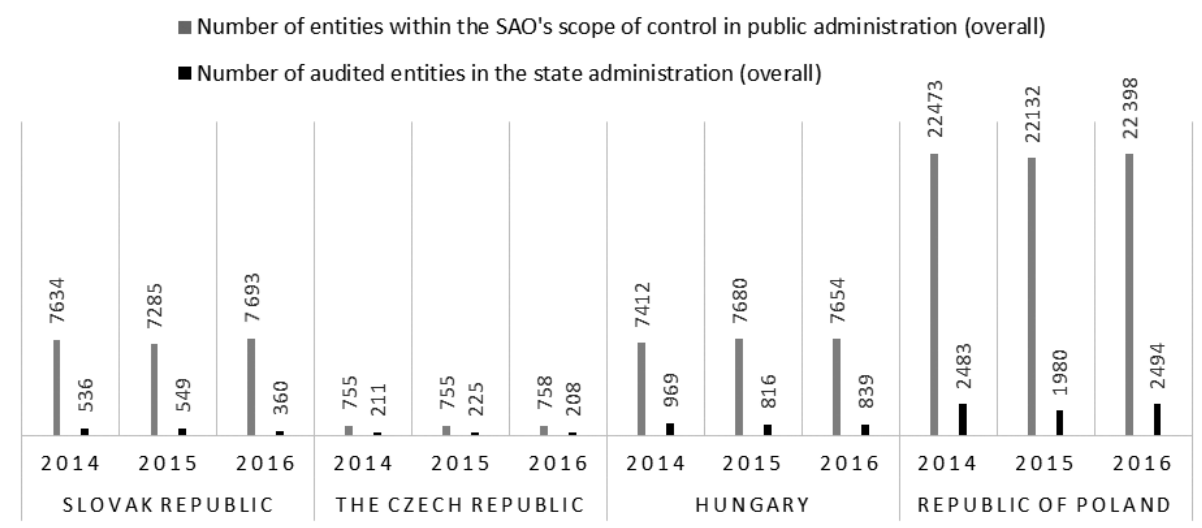

Figure 2. Scope of control of the SAO and the number of audited entities in public administration Source: author.

On the other hand, the SAO in Hungary places great emphasis on auditing internal systems of checks and balances of the authorities of local self-government, which form the basis for financial management and the correctness of performed operations, protection against corruption as well as control of financial equilibrium and of how the authorities of local self-government manage their finances. Audits always focus on the areas with presumably greatest risk. In 2016, the investment activity of local authorities of self-government was a priority, and since mid-2015, the debt of municipalities has been another one. There are also intensive inspections of business entities established by municipalities, as well as museums. In 2016, 29 basic and 33 follow-up audits were carried out in authorities of self-government, 80 audits were carried out in companies established by authorities of self-government and 14 city museums were audited.

In the structure of the Slovak SAO, the territorial self-government authorities are audited mainly by local SAO auditors, who are based in all eight higher territorial units of the Slovak Republic. Their control activity and findings point to long-term serious and persistent deficiencies in the activity of the self-government authorities. These are similar problems with the management of public resources, which also manifest themselves in how the state administration organizations manage the resources allocated to them, although there are certain area-specific issues faced by the self-government authorities. In particular, small municipalities are not able to cope with the whole complex of legislative and non-legislative conditions governing their activities. This includes, in particular, 
the lack of professional capacity of the management and the employees of selfgovernment authorities and deficiencies in organizational structures.

\section{RESULTS, RISK SPECIFICATION AND SUGGESTIONS}

In most countries, the entire public sector, including territorial self-government authorities and state-owned companies, falls under the scope of the SAO's control. Article 18, section 3 of the Lima Declaration states that the entire management of public funds is subject to audits by the Supreme Audit Office, regardless of whether and how this is reflected in the total state budget. Being excluded from the state budget must not lead to the exclusion of these sub-areas from the scope of control (for example, the management of state funds).

In general, we can conclude that the broader scope of SAO control activity, with an impact on the authorities of self-government, is a more far-reaching audit of public finances as a whole, which is particularly important in fiscal decentralization and the transfer of competences to the authorities of self-government.

However, human resources constitute an area of risk when the scope of control is so broad.

The weakness of the audit activity of the Slovak SAO includes insufficient specialization of the auditors in individual public policies - the SAO's auditors are not specialized in certain areas of control, such as public procurement, handling of assets, public finance management, accounting, or labor relations. One inspector must be able to control all areas, and not specialize only on selected areas of control. In 2007, the SAO's competencies with respect to auditing selfgovernment authorities were expanded. As a result, the number of staff increased by 20 persons compared to 2006 , with the limit of the number of employees for 2007 having been established by the state budget law at 289, out of which 25 persons were approved for work in the public interest and 269 persons for the civil service. In the analyzed period of 2014-2016, the number of the SAO auditors was much lower (e.g. in 2016, there were 235 auditors), while the SAO's audit competencies with respect to the authorities of self-government remained unchanged. Here again, it is worth pointing out a comparison of the number of audits carried out by a single auditor, taking into account the fact that in the Czech Republic, where the SAO does not exercise its audits over self-government authorities, a single auditor accounts for 0.7 audits per year, whereas in the other V4 countries, where the SAO's jurisdiction also extends over the authorities of self-government, this number is much higher (in the Slovak Republic about 2.3 audits per an auditor, in Hungary 1.5 and in Poland about two audits per an auditor, respectively). It follows that the auditors have no room for specialization, 
they must have a full command of the principles of audit as applied in practice. It is therefore appropriate to increase the number of auditors with specialization in individual public policies and thus to reinforce the performance of audit activities in public administration.

Another risk of including the authorities of self-government in the scope of SAO control is the potential lack of coordination of audit performance between itself and other controlling authorities auditing self-government authorities, leading to potential duplicity of audits. In this case, we propose streamlining and rationalizing control activities and cooperation of all control bodies. It is necessary to find forms of methodological guidance and coordination of control activities.

The number of audited local government entities is only slightly less than half of all the audited public administration entities, with the number of audit findings in the local government being much higher than in the state administration. From the public finances viewpoint, the area of local self-government has been continuously a higher risk area in terms of adherence to budgetary rules, bookkeeping and asset management. The ability of self-government authorities to cope with the requirements of strategic management of their development appears to pose a significant risk, especially in case of smaller municipalities and towns. All levels of self-government authorities have been found to lack internal audit, to have problems with disclosure of information in the sense of public access to information. Therefore, we propose that audit actions need to address these areas in particular.

\section{CONCLUSION}

The existence of the Supreme Audit Office in all V4 countries is enshrined in the constitution of the respective countries and its activity is regulated by the SAO Act. The paper has assessed how they have solved control of public finances, and as former transition economies they started in similar positions, on similar foundations, including the area of public finances and their control. As a result of our research, these countries do not differ much nowadays, and work on similar principles.

We assessed the SAO audit activity in the Slovak Republic and we compared the results with other V4 countries. We conducted an analysis of the scope of control, the number of audits carried out, and we evaluated the auditors' workload. The obtained results point to the fact that the scope of the SAO's control in the countries of Slovakia, Hungary and Poland covers the entities of the entire public sector unlike in the Czech Republic, where the SAO audit competence extends only over the state administration. The authorities of self-government are not 
subject to the scope of the SAO control. The greatest percentage of entities falling under the controlling jurisdiction of the SAO were audited in the Czech Republic, where we also find the lowest workload faced by the auditors as regards the number of audits carried out per single auditor. This is mainly due to the fact that the SAO in the Czech Republic does not audit the authorities of self-government; therefore, its auditing duty applies to fewer entities, allowing the auditors a narrower specialization. Insufficient specialization of auditors in individual public policies has been specified as one of the risks of the SAO audit activity in general when a relatively small number of auditors have full command of how the executive audit principles are applied in practice. The possibility of performing duplicate audits is specified as an additional possible risk if the controlling power of the SAO extends to the authorities of self-government. A long-term risk is the area of territorial self-government from the point of view of public finances in respect to budgetary rules, accounting, and asset management.

To eliminate the specified risks, we suggest:

- expanding the number of auditors with individual public policy specialization, thus strengthening the performance of control activities in public administration;

- streamlining and rationalizing control activities and cooperation of all control bodies. It is necessary to find forms of methodological guidance and coordination of control activities;

- target control actions primarily to self-government areas at all levels.

\section{REFERENCES}

Barrett, P. (2012): Performance Auditing-Addressing Real or Perceived Expectation Gaps in the Public Sector. Public Money and Management 32(2): 129-136.

Beetham, D. - Weir, S. (2000): Democratic Audit in Comparative Perspective. Lanth, H. J. - Pickel, G. - Wegel, C. (eds): Demokratiemessung. Opladen: Westdeutscher Verlag, pp. 73-88.

Benčo, J. - Kamod'a, J. - Nemec, J. (2001): Kontrola vo verejnom sektore. [Control in the Public Sector]. Banská Bystrica (Slovakia): Matej Bel University.

Bovaird, T. - Löffler, E. (2003): Evaluating the Quality of Public Governance: Indicators, Models and Methodologies. International Review of Administrative 69(3): 313-328

Brusca, I. - Caperchione, E. - Cohen, S. - Manes Rossi, F. (eds) (2015): Public Sector Accounting and Auditing in Europe: The Challenge of Harmonization. Basingstoke: Palgrave Macmillan.

Buchanan, R. - Simpkins, K. (2001): A New Age for Public Auditing. Chartered Accountants Journal of New Zealand July: 8-11.

Cordery, C. J. - Hay, D. C. (2018): Supreme Audit Institutions and Public Value: Demonstrating Relevance. Financial Accountability \& Management, doi: 10.1111/faam.12185.

Halásková, M. - Halásková, R. (2017): Public Expenditures in Areas of Public Sector: Analysis and Evaluation in EU Countries. Scientific Papers of the University of Pardubice - Series D 40(2): 49-60. 
Hay, D. - Cordery, C. (2018): The Value of Public Sector Audit: Literature and History. Journal of Accounting Literature 40: 1-15.

Hendrych, D. (2009): Správni věda teorie veřejné správy. [Correct Science Theory of Public Administration]. Praha: Wolters Kluwer.

Iacovino, N. M. - Barsanti, S. - Cinquini, L. (2017): Public Organizations between Old Public Administration, New Public Management and Public Governance: The Case of the Tuscany Region. Public Organization Review 17(1): 61-82.

Jankovics, L. (2016): Local Government Finances in Hungary: From the Culprit of Fiscal Slippages to a Source of Stability? Society and Economy in Central and Eastern Europe 38(4): 455-478.

Klierova, M. - Kútik, J. (2017): One Stop Government - Strategy of Public Services for Citizens and Businesses in Slovakia. Administratie si Management Public (28): 66-80.

Kočiš, E. (2007): The Status of the SAO SR in the Control System and Some Results from the Office's Inspection Activities. Conference of the SAO SR: Access to Justice - Barriers and Basis.

Králik, J. - Kútik, J. (2013): Kontrolný systém a jeho subsystémy vo verejnej správe. [Control System and Its Subsystems in Public Administration]. Plzeň: vyd. Aleš Čeněk, s.r.o.

Maličká, L. (2017): Determinanty zadlženosti miestnych samospráv Slovenskej republiky. [Determinants of Local Government Indebtedness to the Slovak Republic]. Politická ekonomie 65(3): 301-315.

Matějová, L. - Nemec, J. - Křápek, M. - Klimovský, D. (2017): Economies of Scale on the Municipal Level: Fact or Fiction in the Czech Republic? NISPAcee Journal of Public Administration and Policy 10(1): 39-59.

Medved', J. - Nemec, J. (2011): Verejné financie. [Public Finance]. Bratislava: Sprint.

Meričkova, B. M. - Nemec, J. - Svidronova, M. (2015): Co-Creation in Local Public Services Delivery Innovation: Slovak Experience. Lex Localis - Journal of Local Self-Government 13(3): 521-535.

Nagy, S. (2012): The Role of Supreme Audit Institutions in Fight against the Consequences of Financial and Economic Crisis: A Theoretical Approach. In: Farkas, B. - Mező, J. (eds): Crisis Aftermath: Economic Policy Changes in the EU and Its Member States Conference Proceedings. Szeged: University of Szeged, pp. 270-282.

Nemec, J. - Ochrana, F. - Pavel, J. - Šagát, V. (2010): Kontrola ve veřejné správě. [Control in Public Administration]. Praha: Wolters Kluwer.

Nemec, J. (2015): Public Policy in the Czech Republic. Central European Journal of Public Policy 9(1): 4-5.

Nikodým, D. (1969): Kontrola v štátnej správe a v hospodárskej správe ČSFR. [Control in the State Administration and in the Economic Administration of the CSFR]. Bratislava: SAV.

Oláh, M. (2005): Interný audit vo verejnej správe. [Internal Audit in Public Administration]. Bratislava.

Oláh, M. - Šidelský, L. - Cibák, L'. (2009): Finančná kontrola. [Financial Control]. Bratislava: Merkury s.r.o.

Rakšnys, A. V. - Valickas, A. (2016): Transformations of Public Sector Managers' Role and Organizational Culture in the Context of Modernization Traditions. Public Policy and Administration 15(4): 687-701.

Reddy, P. - Nemec, J. - De Vries, M. S. (2015): The State of Local Government. Public Policy and Administration 14(3): 160-176.

Redmayne, N. B. - Bradbury, M. E. - Cahan, S. (2010): The Effect of Political Visibility on Audit Effort and Audit Pricing. Accounting and Finance 50(4): 921-939.

Stapenhurst, R. - Titsworth, J. (2001): Features and Functions of Supreme Audit Institutions. PREM-notes 59: 1-4. 
Škultéty, P. (2008): Verejná správa a správne právo. [Public Administration and Administrative Law]. Bratislava: VEDA.

Špalková, D. - Špaček, D. - Nemec, J. (2015): Performance Management and Performance Appraisal: Czech Self-Governments. NISPAcee Journal of Public Administration and Policy 8(2): 69-88.

Tej, J. (2002): Ekonomika a manažment verejnej správy. [Economics and Management of Public Administration]. Presov: University of Presov.

Annual reports of SAO of the Slovak Republic for the years 2014-2016.

Annual Reports of the SAO of the Czech Republic for the years 2014-2016.

Annual reports of the SAO in Hungary for the years 2014-2016.

Annual Reports of the SAO in Poland for the years 2014-2016.

Act no. 39/1993 Coll. on the Supreme Audit Office of the Slovak Republic, as amended.

Act no. 166/1993 Coll. on the Supreme Audit Office of the Czech Republic, as amended.

Act LXVI of 2011 on the State Audit Office of Hungary.

Dz. U. No. 227, item 1482 Supreme Audit Office Act in Poland.

Open Access. This is an open-access article distributed under the terms of the Creative Commons Attribution-NonCommercial 4.0 International License (https://creativecommons. org/licenses/by-nc/4.0/), which permits unrestricted use, distribution, and reproduction in any medium for non-commercial purposes, provided the original author and source are credited, a link to the CC License is provided, and changes - if any - are indicated. 